IV i 1. poł. V wieku, oraz uwypuklić na tle rozwoju wczesnochrześcijańskiej myśli eucharystycznej cechy charakterystyczne tej teologii. Wymagało to żmudnego i wnikliwego przestudiowania wszystkich dzieł najważniejszych autorów tego okresu (Hilarego z Poitiers, Ambrożego, Augustyna, Hieronima), ponieważ żaden z nich nie poświęcił oddzielnego dzieła Eucharystii, ale każdy zawarł różne elementy eucharystycznej doktryny w wielu swoich pismach. Tym cenniejszy jest rezultat, dający wyczerpujący obraz zagadnienia, a równocześnie inspirujący do dalszych badań, Autor bowiem nigdy nie upraszcza analizy i nie wyprowadza zbyt ogólnych czy pochopnych wniosków, lecz analizując z uwagą każdy szczegół wypowiedzi Ojców, wskazuje na różne trudności w interpretacji, nie przemilcza wątpliwości, jakie nasuwa dany tekst, sugeruje zrównoważone rozwiązania, zawsze wierne duchowi wypowiedzi autora patrystycznego. Podziw wzbudzaja wzorcowo zredagowane bogate przypisy źródłowe, pozwalające śledzić oryginalne łacińskie wypowiedzi analizowanych autorów i dające wyczerpującą egzemplifikację tez prezentowanych $w$ rozprawie.

Recenzowana monografia stanowi udane ukoronowanie wieloletnich badań nad sakramentologią i duszpasterstwem łacińskich Ojców Kościoła. Będzie z pewnością stanowić punkt odniesienia dla teologów różnych specjalności, jako sumaryczne, a równocześnie niezwykle szczegółowe kompendium wiedzy na temat rozumienia podstawowego sakramentu wtajemniczenia chrześcijańskiego w Kościele zachodnim pierwszego tysiąclecia.

ks. Mariusz Szram - Lublin, KUL

\title{
Henry CHADWICK, Augustine of Hippo. A Life, Oxford 2010, Oxford University Press, ss. 177.
}

Wydawnictwo Oksfordzkie opublikowało pośmiertnie dzieło znanego emerytowanego profesora historii Kościoła wczesnego średniowiecza z Oksfordu i Cambridge - Henry Chadwicka (1920-2008). Wstęp do niego napisał sam Peter Brown, znawca problematyki augustyńskiej i na nowo opracowanego, na podstawie jego hagiograficznych biografii, życiorysu św. Augustyna (354-430). Prof. Chadwick zasłynął thumaczeniem Contra Celsum Orygenesa (Cambridge 1965) i wyjaśnianiem jego nauki, by później zająć się św. Augustynem, którego życie i dzieło (słynne jest jego thumaczenie Wyznań, New York 1991) poznał na tyle, by stać się kompetentnym jego znawcą. Obecne wydanie, jest pierwszą kompletną publikacją manuskryptu (szkicu), znalezionego pośmiertnie w jego notatkach. Chociaż H. Chadwick, na prośbę wydawnictwa Oxford University Press, wydał już wcześniej jej skróconą formę (1981) oraz dwie skondensowane wersje (1986, 2001), to jednak dopiero to dzieło jest tym, o którym myślał od samego początku, i dopiero ono pokazuje cały jego kunszt literacki.

Na książkę składa się 11 rozdziałów obejmujących chronologicznie życie i działalność św. Augustyna. Poprzedzone są one wspomnianym wstępem Pe- 
tera Browna, podziękowaniem brata zmarłego profesora za wydanie obecnego manuskryptu, spisem treści i wykazem stosowanych skrótów, a zakończone podaniem listy łacińskich manuskryptów i wydań oraz ich angielskich przekładów (do 2009 r.), dokonanej przez Gilliana Clarka, a wreszcie alfabetyczny indeks rzeczowy.

Pierwszy rozdział (Dane biograficzne), dotyczy przedstawienia środowiska życia Augustyna na tle jego wzmianek z Wyznań oraz innych dokumentów historycznych. Autor bierze tu pod uwagę środowisko rodzinne w Tagaście, droge dojścia młodego Augustyna do bycia nauczycielem retoryki, relacje z manichejczykami, działalnością w Mediolanie, związku z filozofią platońską, spotkanie ze św. Ambrożym, który miał decydujący wpływ na jego nawrócenie. Rozdział drugi (Cassiciacum i śmierć Moniki w Ostii) omawia jego duchowe przeżycie w Cassago di Brienza u stóp Alp, śmierć matki Moniki w Ostii oraz chrzest w Mediolanie z rąk św. Ambrożego. Trzeci rozdział (Na powrót w Tagaście) opisuje jego działalność nauczycielską i apologetyczną w Tagaście, w zwlaczaniu argumentów manichejczyków. W czwartym rozdziale (Odkrywając Kościót) Autor ukazuje Augustyna na tle wspólnoty mnichów, którą założył w Tagaście, ślubując celibat. Piąty rozdział (Biskup) opisuje szczegóły zostania kapłanem, a następnie biskupem Hippony, po śmierci tamtejszego biskupa Waleriana. Rozdział szósty (Chrześcijaństwo Pótnocnej Afryki) podaje specyfikę chrześcijaństwa Pólnocnej Afryki, w której części Hipponie, Augustyn był biskupem. W kolejnym rozdziale (Kultura chrześcijańska) omawia elementy charakterystyczne kultury chrześcijańskiej, jaką tworzyła tamtejsza wspólnota kościelna. Omawia tu szczegółowo Wyznania Augustyna oraz wartość i piękno estetyki na podstawie jego nauczania. Rozdziały ósmy i dziewiąty są po kolei poświęcone zwalczaniu przez Augustyna błędów Donata (Podzieleni chrześcijanie) i Ariusza (Wyróżnić Trójcę). W rozdziale dziesiątym (Dwa państwa) omawia dzieło O państwie Bożym, które Augustyn pisze obsadzając na swej stolicy biskupiej kapłana Herakliusza. Ostatni, jedenasty rozdział (Wolność $i$ laska), omawia błędy Pelagiusza, z którą to sektą miał się zmagać biskup Hippony w ostatnich dwóch dekadach swego życia.

Książka nie opisuje już śmierci Augustyna w oblężonej przez Wandalów Hipponie, w 430 r., ani o zdobyciu i spaleniu miasta oraz cudownie uratowanej biblioteki augustyńskiej. Pewnie autorowi nie starczyło czasu, albo metodycznie uznał te informacje za mniej ważne i znane przez czytelnika, w porównaniu z dziełami Augustyna, które omawiał w aspekcie poszczególnych herezji: donatyzmu, arianizmu i pelagianizmu.

Książka H. Chadwicka o Augustynie, jedna z wielu dziś biografii tego świętego, jest kolejną perełką próbującą oddać obiektywnie życiorys i twórczość jednego z największych gigantów Kościóła katolickiego. Nie pretenduje do bycia jedyną i wyłączną biografią świętego, jednakże przez żywy i łatwy język może przyczynić się do pokazania tego świętego komuś, kto potrzebuje w sposób przystępny poznać jego dzieje. Odsłania przy tym ciekawe i nieznane dotąd wydarzenia, zaczerpnięte z innych źródeł, które pokazują Augustyna w bardziej ludzkich 
uwikłaniach życiowych, tak bardzo podobnych do naszych. Należy więc podziękować ludziom związanym bliżej ze zmarłym $\mathrm{H}$. Chadwickiem oraz wydawnictwu z Oksfordu, za znalezienie i udostępnienie jego manuskryptu dla szerokiego grona zainteresowanych.

ks. Ryszard Groń - Wrocław, PWT

\begin{abstract}
Ks. Józef POCHWAT MS, „Misterium iniquitatis”. Studium tajemnicy nieprawości w dzielach Jana Kasjana (360-435), Kraków 2012, Wydawnictwo La Salette, ss. 384.
\end{abstract}

Na rynku wydawniczym można spotkać coraz częściej tytuły, które związane są z tematyką świata nadprzyrodzonego, a w szczególny sposób z działaniem złego ducha wobec człowieka. Obok wywiadów i opisów osobistych doświadczeń trudno niekiedy znaleźć pogłębione opracowania teologiczne poświęcone powyższym zagadnieniom. Brakowało dotąd na polskim gruncie specjalistycznych monografii prezentujących, jak ta kwestia przedstawiała się w epoce Ojców Kościoła. Za swoisty punkt wyjścia w tym zakresie należy uznać 17 . tom znanej serii wydawniczej redagowanej przez ks. prof. Henryka Pietrasa SJ, pt. Demonologia w nauce Ojców Kościoła (Kraków 2000), zawierający materiały z sesji naukowej zorganizowanej przez Sekcję Patrystyczną przy Komisji ds. Nauki Katolickiej Konferencji Episkopatu Polski, która odbyła się w Siedlcach w dniach 21-22 września 1998 roku. Do tego tomu został dołączony traktat Hipolita O Antychryście w przekładzie Stanisława Kalinkowskiego (ss. 109-148). Swoistą kontynuację badań zaprezentowanych w powyższym opracowaniu stanowi recenzowana książka ks. Józefa Pochwata MS, pt. „,Misterium iniquitatatis”. Studium tajemnicy nieprawości $w$ dziełach Jana Kasjana (360-435). Jest to pozycja o tyle cenna, iż przedstawia nauczanie autora, którego można nazwać łącznikiem między wschodnią i zachodnią myślą patrystyczną. Urodzony na Wschodzie, późniejsze swoje życie łączy z Zachodem, potrafiąc umiejętnie inkulturować swoje wschodnie doświadczenia. Twórczość Jana Kasjana pozwala spojrzeć szerzej na problemy ówczesnego świata chrześcijańskiego, co Autor monografii dobrze uwypukla.

Ks. J. Pochwat podzielił swoją książkę na dwie zasadnicze części: historyczną i teologiczną. W części historycznej (ss. 21-81) autor pragnie zapoznać czytelnika z dziejami Kościoła w Galii na przełomie IV i V w., przedstawiając tło dziejowe, a więc wojny z barbarzyńcami w tym okresie oraz prezentację problematyki społecznej i sytuacji Kościoła, zwracając przy tym szczególną uwagę na herezje i prześladowania oraz tworząc zarys genezy monastycyzmu chrześcijańskiego w Galii (rozdział I, ss. 22-49). W tej części również została przedstawiona szczegółowa biografia Jana Kasjana, co jest uzasadnione tym, że - jak podaje sam autor - ,jest to jedna z najbardziej tajemniczych postaci pośród pisarzy i Ojców Kościoła" (s. 50). Ks. J. Pochwat, pisząc o życiu i działalności Jana Kasjana, dokonuje niemalże dziennikarskiego śledztwa, co pozwala czytelnikowi, znającemu 